С. 64 - 76. 3. Гуревич Р. С. Інформаційно-телекомунікаційні технології в навчальному процесі та наукових дослідженнях. / Р. С. Гуревич, М. Ю. Кадемія. - К. : Освіта України, 2006. - 390 с. 4. Кадемія М. Ю. Використання електронного навчальнометодичного комплексу в навчальному процесі / М. Ю. Кадемія // Сучасні інформаційні технології та іноноваційні методики навчання у підготовці фахівців: методологія, теорія, досвід, проблеми : [зб. наук. пр.]. - Випуск 8 / редкол.: І. А. Зязюн (голова) та ін. - Київ-Вінниця: ООО «Планер», 2005. - 547 с. 5. Співаковський О. В. Теоретико-методичні основи навчання вищої математики майбутніх вчителів математики з використанням інформаційних технологій : дис. ... д-ра пед. наук / О. В. Співаковський. - Київ, 2003. $535 \mathrm{c}$.

УДК 53(07):371,385

Г. П. Половина,

доиент,

Криворізький педагогічний інститут

ДВНЗ «Криворізький національний університет»

\title{
ПАРТНЕРСЬКЕ НАВЧАННЯ УЧЕНЬ - СТУДЕНТ ПЕДАГОГІЧНОГО ВНЗ У САМОСТІЙНОМУ ВИВЧЕННІ ФІЗИКИ
}

У роботі розглянуто один із підходів підвищення мотивачії навчання при дослідженні явища, яке викликало інтерес. До розв'язання иієї проблеми залучаються вчитель та викладач вищої школи, а також учень та студент педагогічного ВНЗ.

Ключові слова: партнерське навчання, самостійна діяльність, дослідницька робота, творче мислення.

В работе рассматривается один из подходов повышения мотивачии обучения при исследовании явления, которое вызвало интерес. К решению этой проблемы вовлекаются учитель и преподаватель высшей школь, а также ученик и студент педагогичного института.

Ключевые слова: партнерское обучение, самостоятельная деятельность, исследовательская работа, творческое мышление.

In this work one of motivation increase approaches of training at research of the phenomenon with caused interest is considered. To the solution of this problem the teachers and professors of higher educational institution and also the pupil and the student of pedagogical institution are involved.

Key words: partner training, independent activity, research work, creative thinking.

Існує думка, що рівень знань 3 фізики значно знижується 3 того моменту, коли термін навчання в школі змінювався 3 10- 
ти, 11-ти, 12-ти, а потім знову 11 -ти річним навчанням в середній школі, а кількість годин стала меншою. Більшість учнів за весь навчальних рік ні разу не бувають опитаними усно, коли б вчитель міг виявити в них наявність самостійного та творчого мислення, вміння сформулювати власну думку.

Mета статmі - показати самостійну діяльність в навчанні через співпрацю школи та ВНЗ.

Щоб дати можливість розвиватися учневі творчо, проводяться олімпіади різного рівня, фізичні турніри МАН, ведуться гуртки тощо. Але 70\% творчих робіт, які називаються науково-дослідними, взяті з Інтернету, без посилання на літературні джерела і без жодної власної думки. У $30 \%$ членів МАНу - справді творчі, з дослідженнями та висновками роботи. Ці дані наведено викладачами кафедри фізики та методики їі навчання педінституту, які рецензують дослідницькі роботи учнів, що захищаються в МАН.

Викладачі фізики, які працюють 3 першим курсом, зауважують, що більшість студентів мають знання за середню школу на рівні знань формул та формувань законів. А задачі розв'язують на рівні «візьмемо формулу та підставимо в неї значення». Більшість 3 них не бачать функціональної залежності між фізичними величинами, що входять до формул, які вони використовують.

Теоретики і практики педагогіки, психології, методики навчання фізики працюють над проблемою значного підвищення якості знань. Нині більшість дослідників схиляються до думки, що низький рівень знань пояснюється відсутністю внутрішньої потреби мати знання високого рівня, тобто відсутністю мотиву навчання. Проблемою самостійної роботи 3 метою формування стійкого мотиву навчання займалися теоретики та практики: П. Атаманчук, А. Бендера, В. Буряк, О. Сергєєв та ін..

Щоб викликати потребу до навчання, треба змінити технологію навчання, спрямовуючи переорієнтацію діяльності викладача від організаційно-інформаційної до інформаційнотехнологічної, спрямовуючи навчальну діяльність учнів на самостійну пошуково-пізнавальну діяльність, яка містить такі компоненти:

- Мотиваційний - вироблення стійкого позитивного зацікавлення суб'єктів навчання явищами природи, розвиток допитливості, бачення перспективи наслідків навчання фізики. Це внутрішній чинник, який спонукає учня до саморозви- 
тку, до навчання не заради оцінки, а для засвоєння знання та подальшому його використанні.

- Змістовний компонент включає знання, уміння і навички, на яких грунтуються спонукальні проблеми учня під час вивчення понять, явищ, процесів та нові знання та способи дій, які викликані певними досягненнями.

Є такі структурні компоненти мотивації:

- мотивація спонукальної ініціації, що забезпечує активізацію навчальної діяльності;

- мотивація вибору мети навчальної діяльності;

- мотивація реалізації потреб суб'єктів навчання.

У мотиваційній пізнавально-пошуковій діяльності учнів найбільш повно виявляється пізнавальний інтерес, в якому виявляється взаємозв'язок інтелектуальної, емоційної та вольової сфери особистості учня [1, с. 30].

Розглянемо декілька факторів, що сприяли б появі та розвитку мотиву навчання.

На уроці фізики під час вивчення нового матеріалу, розв'язку задач, написанні творчих робіт, лабораторних, контрольних, роботі з книгою, розв'язку домашніх задач створюються ситуації, що сприяють самостійній роботі учнів. Але цього не досить, бо як показує взаємодія зі студентами першого курсу вони не вміють і не хочуть працювати самостійно. Навчити працювати самостійно та викликати мотив навчання повинна школа.

Метод, який найчастіше використовують вчителі фізики, щоб створити внутрішній мотив навчання, є викликанням інтересу до процесу навчання. Найбільш дійовий результат виявляється при використанні експериментального в сукупності 3 теоретичними та практичними методами навчання. При цьому слід використовувати експериментальний метод так, щоб він не перетворився на розвагу, а щоб він викликав бажання розібратись у явищі, що присутнє в експерименті, довів теорію і актуалізував нові питання для більш глибокого розуміння суті явища.

Інтерес та мотивація навчання 3'являються тоді, коли учень працює самостійно.

Проблемою самостійної навчальної діяльності як студентів так і учнів займалися багато вчених. Зокрема, в роботі [2, c. 134] показано, що правильно організований фізичний експеримент не тільки активізує мисленнєву діяльність студентів, що $\epsilon$ необхідною передумовою розвитку їхньої пізнава- 
льної активності, але і викликає стійкий інтерес до досліджуваного явища, сприяє більш глибокому засвоєнню й усвідомленню фізичних законів і явищ.

Як показує практика вчителів та викладачів ВНЗ, що самостійна діяльність тих, хто навчається призводить до виникнення мотивів навчання. Питання самостійної діяльності при навчанні під час виконання лабораторних, творчих робіт, під час розв'язку задач, самостійних досліджень висвітлено у багатьох роботах.

Цікаві дослідження протягом декількох років були зроблені вчителем фізики Довгинцівського ліцею В. Голобородько. Учні цього ліцею брали участь в міських та Всеукраїнських олімпіадах, а також захищали роботи на МАН. Бесіди вчителя з учнями-переможцями олімпіад, вивчення документації за результатами змагань свідчать, що кращі результати показують переважно не учні престижних ліцеїв (хоч там перемоги теж $\epsilon$ ), а ті, хто самостійно долав всі перешкоди.

Цікаві результати наведено в [3, с. 277], де є дані за 9 років про перемоги учнів у Всеукраїнських олімпіадах із фізики (результати деяких шкіл та ліцеїв).

\begin{tabular}{|c|c|c|c|c|c|c|c|c|c|}
\hline Розва & 1997 & 1998 & 1999 & 2000 & 2001 & 2002 & 2003 & 2004 & 2005 \\
\hline УФМлКНУ & 14 & 14 & 10 & 6 & 6 & 8 & 5 & 7 & 9 \\
\hline НТУУ ІКПІ & 3 & 1 & - & 1 & - & - & 1 & 1 & 1 \\
\hline $\begin{array}{c}\text { Ліцей № } \\
\text { 145 м.Киї }\end{array}$ & 4 & 1 & 2 & 4 & 5 & 2 & 1 & 1 & 3 \\
\hline $\begin{array}{c}\text { Ліцей № 27 } \\
\text { м.Харків }\end{array}$ & 5 & 4 & 5 & 4 & 6 & 5 & 6 & 5 & 1 \\
\hline $\begin{array}{c}\text { ЛНУ } \\
\text { м.Львів }\end{array}$ & 3 & 7 & 3 & 5 & 3 & 1 & 5 & 7 & 6 \\
\hline $\begin{array}{c}\text { Дніпр.ЛІТ } \\
\text { Рн. }\end{array}$ & - & 1 & - & 1 & 1 & - & 1 & 1 \\
\hline $\begin{array}{c}\text { Одеса Рл } \\
\text { Жовті води } \\
\text { ліцей }\end{array}$ & 2 & 1 & - & 2 & 3 & - & 1 & 1 & - \\
\hline
\end{tabular}

Над проблемою самостійної діяльності учнів та студентів постійно працює кафедра фізики та методики її навчання КПІ ДВНЗ «КНУ». В [4, с. 97] запропоновано інноваційний підхід до організації навчально-дослідницької роботи, реалізованій 
у співпраці викладачів кафедри та ліцею у партнерській роботі над однією і тією ж темою учня та студента «Поверхневий натяг».

У роботі $[5$, с. 204$]$ йдеться про мотивоване управління самостійною діяльністю учнів при вико-

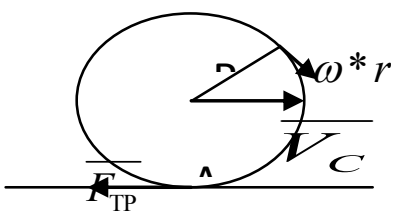

Puс. 1. Швидкість нанні творчих робіт.

Дивний рух біконуса, що розглядається в нашій статті, викликав інтерес у дослідників. Розкриємо зміст цих досліджень.

Щоб зрозуміти, як функціонує біконус на похилих направляючих, слід розглянути під дією яких сил він незвично рухається. По-перше, розглянемо випадок, коли циліндр радіуca $R$ рухається горизонтальною площиною, коли йому зовнішні сили надали швидкість $v$ (Puc. 1).

За відсутності проковзування в точці дотику циліндра 3 землею відносна швидкість циліндра дорівнює нулеві $(v=0)$. Тоді швидкість та прискорення точки C:

$$
v_{c}=\omega R, a_{c}=\beta R
$$

Для т. А: $v=v_{c}+\omega_{x} R$

Якщо $r=R=0$, тобто в т. А $v=0$, то $v_{C}=-\omega R$ і так як $\omega \perp R$, то $v_{c}=\omega R$.

При цьому слід пам'ятати, що вектор $\omega$ спрямований так по відношенню до $v_{\mathrm{c}} \mathrm{i} R$, що якщо дивитися 3 кінця вектора $v_{C}$, то найкоротший поворот від $\omega$ до $\mathrm{R}$ - проти годинникової стрілки.

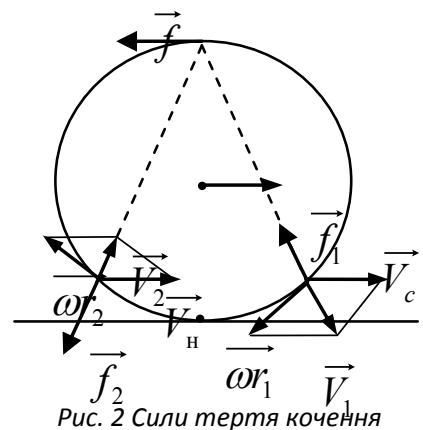

При коченні циліндра з боку опори діють дві сили (двигун не підключений).

Сила тормозного тертя $F_{\text {тр }}$, яка спрямована в протилежний бік від $v_{\text {c }}$. Ця сила зменшує $v_{\text {c }}$, але вона має такий же напрямок що і обертання вектора $\omega$, що збігається з напрямом обертання циліндра. Ця сила зменшує $v_{\text {c }}$, але збільшує $\omega$. За відсутності проковзування ця сила перетворює енергію 
поступального руху на енергію обертання. Це сила тертя спокою, яка і є причиною обертання циліндра. Ця сила консервативна, вона не виконує роботи, не зменшує енергії тіла.

Розглянемо дисипативну силу тертя кочення f, яка залежить від швидкості близьких до опори точок по відношенню до цієї опори. На (Puc. 2) сила $\mathrm{f}$, яка $\epsilon$ сумою сил: $f_{1}=-k\left(V_{1}\right) \vec{V}_{1}$ та $f_{2}=-k\left(V_{2}\right) \vec{V}_{2}$, де $f_{1}$ та $f_{2}-$ сили, що діють 3 боку опори на тіло поблизу точки дотику тіла до опори. $k(V)$ - коефіцієнт, який залежить

від швидкості.

Сила $f_{1}$ заважає передній частині колеса наближенню до опори, а $f_{2}$ - заважає задній частині колеса віддалятися від опори. Сила $f$ направлена назустріч $\mathrm{V}_{\mathrm{c}}$, а точка іï прикладання знаходиться вище $\mathrm{V}_{\mathrm{c}}$, тому $f$ зменшує $\mathrm{V}_{\mathrm{c}}$, а момент цієї сили зменшує $\omega$. Ця сила зменшує кінетичну енергію і поступального i обертального рухів. Ця сила тим більша, чим більша відносна швидкість тих тіл, між якими вона діє.

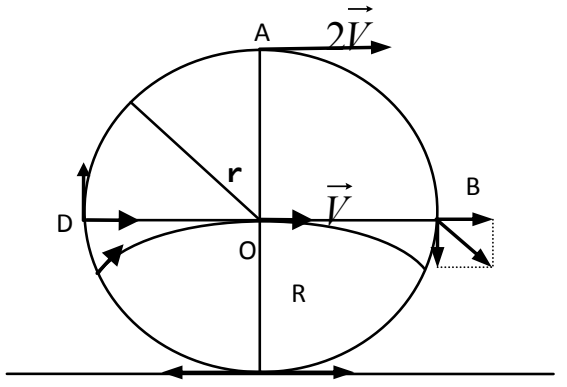

C

Pис. 3. Швидкості різних точок диска

при коченні

Слід зауважити, що під час руху диску циліндра чи кулі поверхнею (без проковзування) різні їхні точки відносно осі обертання чи відносно нерухомого спостерігача мають різну швидкості [6, с. 61].

Розглянемо, чому дорівнює лінійна швидкість будь-якої точки відносно осі обертання. За час рівний періоду обертання точка на поверхні рухомого диску пройде шлях $S=\frac{2 \pi r}{T}$, крім того $V_{\text {лін }}=\omega r$ але $\omega=\frac{2 \pi}{T}$, отже $V_{\text {лін }}=\frac{2 \pi r}{T}$.

Визначимо швидкість точок A, B, C, D, що знаходяться на ободі диску, відносно нерухомого спостерігача (Рuc. 3). 
Швидкість точок обода відносно нерухомого спостерігача складається 3 двох швидкостей: поступального руху та обертового. $V_{A}=2 \vec{V} \quad\left|\mathrm{~V}_{\mathrm{D}}\right|=\left|\mathrm{V}_{\mathrm{B}}\right|=|\mathrm{V} \sqrt{2}|, V_{C}=0$.

Миттєва вісь обертання т. C (начебто диск обертається навколо нерухомої вісі). Модуль швидкості будь-якої т. прямо пропорційний радіусу $\mathrm{R}$ з центром в т. C, де радіус змінюється від 0 до 2R.

Якщо циліндр (диск) буде абсолютно твердий, а поверхня, по якій він повинен рухатися не буде деформуватися, кочення не буде. Але реальні тіла при взаємодії деформуються. На (Puc. 2) показано сила $f_{1}$, момент якої намагається збільшити, а момент сили $f_{2}$ - зменшити швидкість обертання. I якщо деформація абсолютно пружна, то картина симетрична $\mathrm{i}$ момент рівнодійної дорівнює нулю: сумарна сила $\left(\overrightarrow{\mathrm{f}}_{1}+\overrightarrow{\mathrm{f}}_{2}\right)$ спрямована вертикально і проходить через т. О. Горизонтальна складова цієї сили рівна нулеві, отже, сила тертя відсутня (Puc. 4 a). На (Puc. 4 б) показано, що при непружній деформації рівнодійна $\left(\overrightarrow{\mathrm{f}}_{1}+\overrightarrow{\mathrm{f}}_{2}\right)$ не проходить через вісь О, внаслі-
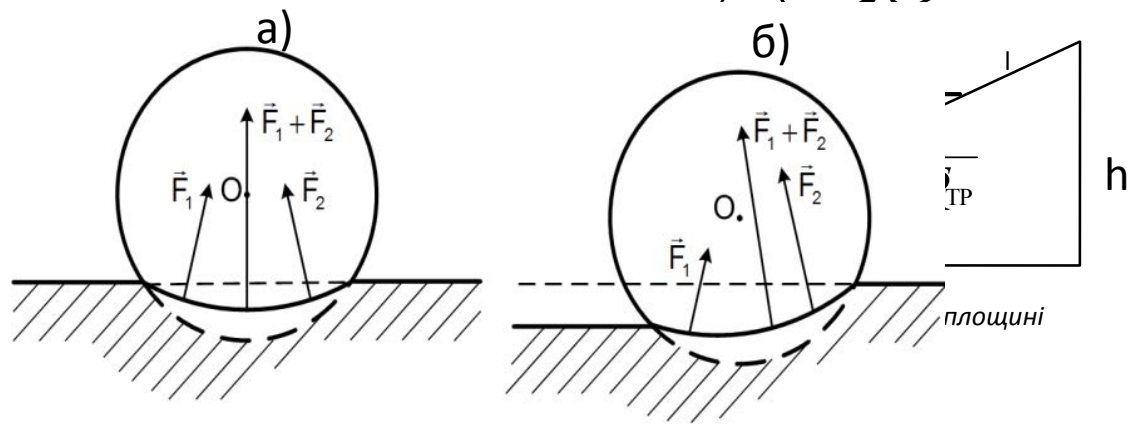

Pис. 4 Сили тертя при пружній (а) та непружній (б) деформаці-

док чого і виникає сила тертя кочення.

Розглянемо рух суцільного циліндра без проковзування по похилій площині. (Рuc. 5) Треба зв'язати $V_{o c}$ i $V_{c}\left(V_{o c}-\right.$ початкова швидкість, $V_{c}-$ кінцева). Це буде змінний рух. Змі- 
нюються швидкості, а тому змінюватиметься сила тертя кочення.

За другим законом Ньютона для поступального та обертального руху маємо:

$$
\begin{aligned}
& m \bar{g}+\overline{F_{R}}+\overline{\mathrm{f}}+\overline{F_{R}}=\overline{m a} ; \quad \overline{(1)} \\
& J \beta=\overline{\mathrm{M}_{\mathrm{mg}}}+\overline{\mathrm{M}_{\mathrm{FR}}}+\overline{\mathrm{M}_{\mathrm{f}}}+\overline{\mathrm{M}_{\mathrm{TP}}} ; \quad \text { (2), де } J-\text { момент іне- }
\end{aligned}
$$

рції циліндра

(1) спроектуємо на ох; (2)- на оу, враховуючи, що $a_{c x}=a_{c} ; \beta_{Y}=\beta$

$$
\begin{aligned}
& m a_{c}=m g \sin \alpha-\mathrm{f}-\mathrm{F}_{\mathrm{TP}}\left(1^{\prime}\right) \\
& J \beta=-\mathrm{fr}+F_{\mathrm{TP}} R ; \quad\left(2^{\prime}\right), \text { । } F_{\mathrm{TP}} R=J \beta+\mathrm{fr}_{1} ; \quad \text { звідси (1) } \\
& F_{\mathrm{TP}}=\frac{J \beta+\mathrm{fr}}{\mathrm{R}}, \text { де } J=\frac{m R^{2}}{2} .
\end{aligned}
$$

Після підстановки маємо:

$$
m a_{c}=m g \sin \alpha-f+\frac{R(j \beta+f r)}{R}
$$

$$
m a_{c}=m g \sin \alpha-f+\frac{j \beta R}{R}+\frac{f r R}{R}
$$

враховуючи, що $\beta=\frac{a_{c}}{R}$; Для циліндра

$$
\begin{aligned}
& m a_{c}=m g \sin \alpha-a+\frac{m R^{2}}{2 R} \frac{a_{c} R}{R}+\frac{f_{r}}{R} R \quad \begin{array}{r}
\text { Рис.6 Біконус для розрахунку його } \\
\frac{3}{2} m a_{c}=m g \sin \alpha-f\left(1+\frac{r}{R}\right)(3)
\end{array}
\end{aligned}
$$

Звідси слідує, що:

Якщо $f\left(1+\frac{r}{R}\right)>m g \sin \alpha, a_{c}<0-$ сповільнений рух

Якщо $f\left(1+\frac{r}{R}\right)<m g \sin \alpha, a_{c}>0-$ прискорений рух 
Якщо $f\left(1+\frac{r}{R}\right)=m g \sin \alpha, a_{c}=0$ - рівномірний рух

Розрахуємо момент інерції біконуса (Рис. 6)

Розіб'ємо конус на елементарні циліндри, у яких змінним буде радіус. При цьому $\frac{r}{x}=\operatorname{tg} \alpha ; r=x \operatorname{tg} \alpha$; Момент інерції циліндра $I_{\text {циліндра }}=\frac{m r^{2}}{2}$.

Момент інерції елементарного циліндра $d I=\frac{1}{2} r^{2} d m$, де $d m=\rho d V$. Об'єм елементарного циліндра $d V=\pi r^{2} d x$. Тому момент інерції цього циліндра $d I=\frac{1}{2} \pi \rho r^{2} r^{2} d x$; $d I=\frac{1}{2} \pi \rho r^{4} d x$

Момент інерції конуса:

$$
\begin{gathered}
d I=\frac{1}{2} \pi \rho(\operatorname{tg} \alpha)^{4} x^{4} d x ; \quad I=\int_{0}^{L} \frac{1}{2} \pi \rho(\operatorname{tg} \alpha)^{4} x^{4} d x ; \\
I_{\text {кон }}=\frac{1}{2} \pi \rho(\operatorname{tgn} \alpha)^{4} \frac{x^{5}}{5} .
\end{gathered}
$$

Момент інерції біконуса:

$$
I_{\text {бікон }}=\pi \rho(\operatorname{tgn} \alpha)^{4} \frac{x^{5}}{5} \text {. }
$$

Після того як ми розглянули причини появи сили тертя кочення циліндра, розглянемо фізику руху біконуса по направляючих, вгору.

Біконус перебуває в: 1) поступальному русі, піднімаючись по похилим; 2) поступальному русі, опускаючись по твірних біконуса; 3) обертальному русі, підіймаючись по похилим; 4) гвинтовому русі по конусам.

За принципом незалежності руху всі ці чотири рухи не залежать один від одного.

Розглянемо поступальний та обертальний рух кожного 3 конусів. Раніше ми розглядали рух суцільного циліндра по похилій площині. Відмінність руху біконуса від руху диска в 
тому, що радіус обертання біконуса буде змінюватись від $\mathrm{R}$ до 0.

Центр маси в положенні б) (Puс. 7) ближче до точки дотику точки докладання сили реакції опори ніж в положенні а).

На біконус в точках дотику діють сили: Сила тормозного тертя та сила тертя кочення, про які було сказано вище при розгляданні кочення циліндра. Сила тормозного тертя $F_{\text {тP }}$ направлена в бік протилежний до $V_{c}$. Тому вона зменшує $V_{c}$, але момент цієї сили збільшує $\omega$. Вона перетворює енергію поступального руху в енергію обертального. Ця сила при відсутності ковзання - $\epsilon$ силою тертя спокою ( $\left.F_{\mathrm{TP}}\right)$. Тобто вона не змінює енергії.

На біконус діють сили тормозного тертя та сили тертя кочення такі ж як і ми розглядали при рухові циліндра 3 урахуванням непружної деформації при взаємодії циліндра та поверхні, якою вони переміщуються. Відмінність полягає тільки в тому, що циліндр має сталий радіус, а у біконуса при рухові поверхнею направляючих буде змінюватися відстань від точки дотику до центра маси.

3 рис. 8 функціонує біконус при рухові вгору. При цьому кут похилої може бути виражений так:

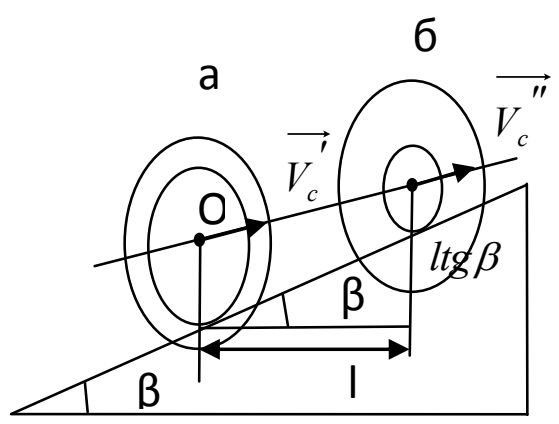

Puc. 7. Висота центру мас по відношенню до точки дотику біконуса

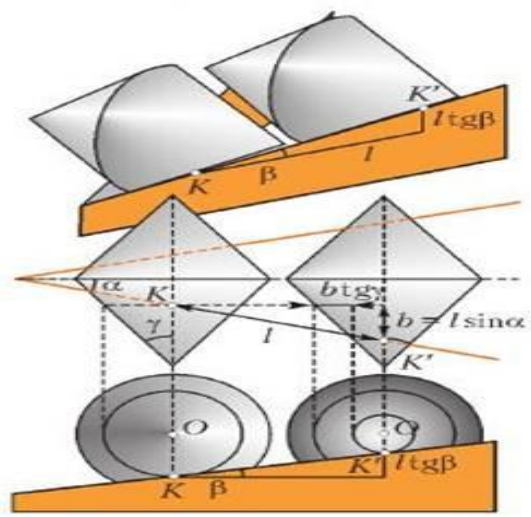

Рис. 8 Рух біконуса вгору $\frac{h}{l}=\operatorname{tg} \beta$, де $h-$ висота, на яку підіймається точка дотику біконуса та одноразово опускається його центр маси на $l \sin \alpha \operatorname{tg} \gamma$, де $2 \gamma$ - кут біконуса при його вершинах, $2 \alpha-$ 
кут між направляючими, по яким рухається біконус.

3 рис. 7 видно, що якщо:

$\operatorname{ltg} \beta>l \sin \alpha \operatorname{tg} \gamma$, то біконус рухається вниз;

$\operatorname{ltg} \beta<l \sin \alpha \operatorname{tg} \gamma$, то біконус рухається вгору;

$\operatorname{ltg} \beta=l \sin \alpha \operatorname{tg} \gamma$, то висота центра біконуса не змінюється.

Такі ж дослідження були

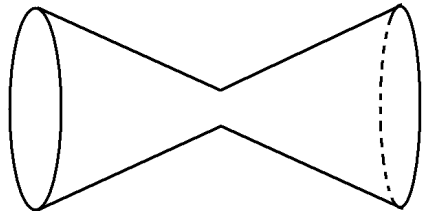

Pис. 9 Біконус, конуси якого з'єднані вершинами проведені для біконуса, конуси якого були з'єднані не основами, а вершинами. (Рис. 9) Направляючі, якими рухається цей біконус, з'єднані вгорі. [7, c. 24]

Запропонований підхід партнерського навчання ученьстудент активізує пізнавальну активність і учня і студента:

- взаємодія шкільного вчителя та викладача вищого навчального закладу дає можливість виявити та корегувати знання учня, а студента готувати до роботи в школі;

- дослідницька робота сприяє розвитку творчого мислення;

- співпраця вчителя 3 науковцями вишу стимулює його професійне зростання;

- для студента така співпраця дає можливість постійно, а не тільки під час практики, набувати досвіду педагогічної діяльності.

\section{Література}

1. Гавриленко О. Мотиваційний аспект діяльності вчителя під час вивчення фізики в школі / О. Гавриленко, М. Садовий // Наукові записки. Серія: Педагогічні науки. Випуск 72. - Ч. 2. - Кіровоград, 2007. - С. 30 - 35. 2. Величко С. До проблеми впровадження комплектів сучасного обладнання для активізації самостійної пошукової діяльності студентів з фізики / С. Величко, І. Мазурик // Наукові записки. Серія: Педагогічні науки. Випуск 72. - Ч. 2. - Кіровоград, 2007. - С. 134 - 138. 3. Всеукраїнська олімпіада з фізики задачі та розв'язки // під ред. Б. Кремінського. - Львів : Свросвіт, 2006. - С. 277 - 304. 4. Голобородько В. А. Партнерське навчання / В. А. Голобородько, Н. С. Погрібна, Г. П. Половина // Збірник наукових праць: Педагогічні науки. - Вип. 57. - Херсон, 2011. - С. $97-$ 102. 5. Половина Г. Мотивоване управління самостійного діяльність учнів при виконанні творчих робіт / Г. Половина, О. Коновал, I. Тополя // Наукові записки. Серія: Педагогічні науки. - Вип. 72. Частина 2, 2007, С. 204-209. 6. Кобушкин В. К. Минимальная фи- 
зика : Часть 1 / В. К. Кобушкин. - Изд-во Ленинградского университета, 1970. - 238 с. 7. Митрофанов А. Вверх по наклонной плоскости / А. Митрофанов // Квант. - 1980. - № 2. - С. 24-25.

УДК 372.851

Н. В. Рашевська, кандидат пед. наук, ДВНЗ «Криворізький національний університет»,

В. В. Ткачук, acnipaнm, Інститут інформаційних технологій $i$ засобів навчання НАПН України

\section{ТЕХНОЛОГІЇ МОБІЛЬНОГО НАВЧАННЯ}

У статті запропоновано тлумачення поняття «мобільне навчання», наведено його переваги та недоліки, розглянуто кілька напрямів реалізащіі мобільного навчання, зокрема для побудови моделі зміманого навчання.

Ключові слова: мобільне навчання, мобільні інформаційнокомунікаційні технології.

В статье приведены определения понятия «мобильное обучение», указаны его преимущества и недостатки, рассмотрены несколько направлений реализации мобильного обучения, в частности для построения модели смешанного обучения.

Ключевые слова: мобильное обучение, мобильные информачионнокоммуникационные технологии.

The article contains several definitions of mobile learning, shows its advantages and disadvantages, discussed several areas of the implementation of mobile learning, in particular, to construct a model of blended learning.

Key words: mobile learning, mobile information and communication technologies.

Як зазначено в проекті Національної стратегії розвитку освіти в Україні на 2012-2021 роки, метою Національної стратегії розвитку освіти є: підвищення доступності якісної, конкурентоспроможної освіти для громадян України відповідно до вимог інноваційного розвитку суспільства, економіки, кожного громадянина; забезпечення особистісного розвитку людини згідно з ії індивідуальними задатками, здібностями, потребами на основі навчання упродовж життя [3].

Аналіз останніх досліджень показав, що пріоритетом розвитку освіти $\epsilon$ впровадження сучасних інформаційнокомунікаційних технологій (IКT), зокрема - технологій та засобів мобільного навчання, які забезпечують удосконален- 